Венчурный бизнес является крайне изменчивым, как и особенности финансирования такого бизнеса. Поэтому требуется постоянный контроль и обновление законодательной базы. Но только обеспечив равновесную защиту интересов сторон высокорисковых инвестиционных отношений, можно ускорить развитие данной области в положительном ключе.

$$
* * *
$$

1. Беседин, А. А. Термин «венчурный» в гражданском законодательстве России / А. А. Беседин // Современные гуманитарные исследования. 2015. № 1. С. 60-62.

2. Габов, А. В. Краудфандинг: законодательное оформление web-модели финансирования в контексте правовой доктрины и зарубежного опыта / А. В. Габов, И. А. Хаванова // Вестник Пермского университета. Юридические науки. 2020. Вып. 47. С. 28-44.

3. Жданова, О. А. Общая оценка правового поля венчурной деятельности в России / О. А. Жданова, К. В. Миляев, А. А. Кушнаренко // Universum: экономика и юриспруденция: электрон. научн. журн. 2016. № 9 (30). URL: https://7universum.com/ru/economy/archive/item/3542 (дата обращения: 12.06.2021).

4. Косьянов, В. А. Проблемы развития венчурного финансирования в России: институциональные аспекты / В. А. Косьянов, В. В. Куликов, Е. Л. Гольдман // Экономика: вчера, сегодня, завтра. 2021. №1-1. С. 9-16.

5. О внесении изменений в отдельные законодательные акты Российской Федерации (в части конвертируемого займа) Законопроект № 972589-7 // [Электронный ресурc] URL: https://sozd.duma.gov.ru/bill/972589-7

6. О внесении изменений в Федеральный закон «О науке и государственной научно-технической политике» Федер. закон от 31 июля 2020 г. № 309-Ф3. Доступ из СПС «КонсультантПлюс». - Текст : электронный.

7. Об инвестиционной деятельности в Российской федерации, осуществляемой в форме капитальных вложений: Федер. закон от 25 февраля 1999 г. № 39-Ф3 ( ред. от 8 декабря 2020 г.). Доступ из СПС «КонсультантПлюс». - Текст : электронный.

8. Свечников, В. А. Актуальные вопросы правового регулирования инвестиционной деятельности в Российской Федерации / В. А. Свечников // Экономика. Право. Общество. 2019. № 1. С. $82-87$.

9. Собченко, Н.В. Особенности юридического оформления договоров между инвесторами и венчурными компаниями / Н. В. Собченко // Политематический сетевой электронный научный журнал Кубанского государственного аграрного университета. 2014. № 95. С. 886-897.

10. Тажудинова, Д. А. Об особенностях инвестиций в ИТ - сектор / Д. А. Тажудинова, Д. С. Аджаматова // Инновации и инвестиции как драйверы социального и экономического развития: сборник статей Международной научно-практической конференции. 2020. С. 26-28.

\title{
Лобовской А.П. \\ Проблемы гражданско-правовой ответственности по договору морской перевозки грузов морским транспортом
}

\author{
Дальневосточный федеральный университет \\ (Россия, Владивосток)
}

doi: 10.18411/trnio-09-2021-79

Научный руководитель: Штыков В.П.

\section{Аннотация}

Целью исследования является анализ действующего законодательства и правоприменительной практики для последующего совершенствования законодательства путем формирования концепций и идей по их разрешению, а также с целью последующих научных дискуссий по данной теме, а также пробелы в законодательстве, в том числе несоответствие действующей правоприменительной практики нынешнему законодательству. Так, в работе рассматриваются вопросы развития гражданского законодательства в сфере морской перевозки грузов. Научная новизна исследования основана на изучении актуальных проблем нормативного регулирования и правоприменительной практики. В результате формируются пути решения текущих проблем, выдвигаются теории совершенствования действующего законодательства Российской Федерации.

Ключевые слова: морская перевозка грузов, ответственность перевозчика, договор морской перевозки грузов, принцип вины. 


\section{Abstract}

The purpose of the research is to analyse the current legislation and law enforcement practice for the subsequent improvement of legislation through the development of concepts and ideas for their resolution, as well as for the purpose of subsequent scientific discussions on the topic, as well as gaps in the legislation including the inconsistency of the current law enforcement practice with the current legislation. Thus, the work deals with the development of civil legislation in the area of carriage by sea of goods. The scientific novelty of the research is based on the study of topical problems of regulatory regulation and law enforcement practices. As a result, ways of solving current problems are being shaped, and theories of improving the current legislation of the Russian Federation are put forward.

Keywords: carriage of goods by sea, carrier liability, contract of carriage of goods by sea, the principle of guilt.

Право международной морской перевозки развивалось в рамках свободы договора и международной унификации, которая традиционно достигалась путем применения более или менее общих правил и стандартов. Морское право появилось ранее других направлений транспортного права, регулирующих перевозки иными видами транспорта, уж в силу того, что все остальные виды транспорта появились значительно позднее морского, поэтому и развитие морского права происходило совершенно индивидуально и самобытно, а принцип свободы договора преобладал еще до появления Брюссельской конвенции 1924 года об унификации некоторых правил о коносаменте (Гаагские правила).

Среди гражданско-правовых договоров, заключаемых в сфере транспорта, договор перевозки грузов является одним из ведущих. Вопрос ответственности перевозчика по договору регулируется Гражданским кодексом РФ, транспортными уставами, и кодексами, но в сфере морской перевозки груза ответственность перевозчика устанавливается Кодексом торгового мореплавания (КМТ РФ). Проблемы определения ответственности перевозчика груза морским транспортом связана с несовершенством российского законодательства.

Первая проблема связанна с ответственностью за нарушение сроков доставки груза. В Гражданском кодексе, транспортными устава и иными законами предусматриваются сроки доставки, а при отсутствии оговоренных сроков действует положение о “разумном сроке”, благодаря которому устанавливается факт просрочки доставки груза. Однако положение о “разумном сроке” довольно растяжимое и нет четких границ. В договоре морской перевозки грузов срок определяется соглашением сторон, он начинается с момента принятия груза для перевозки, и заканчивается моментом выдачи груза. В п. 1 ст. 166 и ст.167 КТМ РФ указаны положения, за которые перевозчик освобождается от ответственности, такие как за просрочку доставки, утрата или повреждение груза, возникших вследствие забастовок, пожаров, навигационных ошибок, непреодолимой силы. За просрочку доставки груза ответственность перевозчика измеряется в денежном эквиваленте и не могут превышать стоимость фрахта, которая подлежит уплате перевозчику по договору, в том случае, если прибыл с задержкой. [2, ст. 166 КТМ РФ]. То есть в данном случае, заказчик может понести убытки за задержку груза, но единственное, на что может рассчитывать заказчик только на выплату суммы, не превышающую стоимость фрахта, ни о какой упущенной выгоде и возмещения убытков речи идти не может. Единственный способ обезопасить себя, заказчик может объявить полную стоимость груза, но это связанно со своими особенностями и дополнительными затратами.

Вторая проблема связана с ответственностью морского перевозчика за не сохранность груза, на практике наиболее часто происходят обращения сторон за разрешением конфликта в судебные органы. Единственным условием наступления ответственности перевозчика за не сохранность груза является принцип вины. Нередко возникают ситуации, когда несмотря на наличие вины перевозчика, ответственность за не сохранность груза не наступает. Перечень условий, закреплены в статье 166 Кодекса торгового мореплавания Российской Федерации. Аналогичный перечень обстоятельств закреплен в статье 4 [2, ст. 166 КТМ РФ], среди 
которых: действия непреодолимой силы, опасности и случайности на море; любые меры по спасанию людей или разумные меры по спасанию имущества на море; пожар, возникший не по вине перевозчика; действия или распоряжения соответствующих властей; военные действия и народные волнения; действия или бездействие отправителя или получателя; скрытые недостатки груза и иные обстоятельства, возникшие не по вине перевозчика, его агентов или работников. Исключением из общего принципа ответственности за вину является правило о навигационной ошибке, в соответствии с которым перевозчик не несет ответственности за утрату или повреждение принятого к перевозке груза либо за просрочку его доставки, если докажет, что они произошли вследствие действия или бездействия в судовождении или управлении судном капитана, других членов экипажа судна либо лоцмана.

Размер ответственности, согласно п. 1 статьи 170 Кодекса торгового мореплавания Российской Федерации, за утрату или повреждение груза не может превышать 666,67 расчетной единицы за место или другую единицу отгрузки либо две расчетные единицы за один килограмм массы брутто утраченного или поврежденного груза в зависимости от того, какая сумма выше. [2, ст. 170 КТМ РФ]. В КМТ РФ не определены единицы измерения просрочки, как например на автомобильном и железнодорожном транспорте, единицей измерения просрочки считаются одни сутки, а на воздушном один час. Отсутствие Единцы измерения не позволяет определить на какой срок опоздал груз.

Третья проблема связана с правовым регулированием договора международной морской перевозки грузов, которая состоит в различии правовых норм, применяемых к возникающим между контрагентами правоотношениям, что вызывает ряд затруднений в судебной практике.

Например: во многих случаях особенностью предъявления претензий к перевозчику на транспорте является обязательная предварительная претензионная процедура. Как правило, это не обязательно в случае причинения вреда жизни и здоровью пассажиров, но необходимо при предъявлении претензий, вытекающих из договора перевозки груза. Претензия предъявляется в письменной форме в течение срока исковой давности и должна быть рассмотрена перевозчиком в течение 30 дней со дня ее получения. К требованиям, вытекающим из морской перевозки грузов, применяется годичный срок исковой давности. Однако Гамбургские правила устанавливают отличающиеся сроки, а именно 90 дней со дня причинения вреда грузу для предъявления претензии и срок исковой данности составляет 2 года. На этом примере видны расхождения в законодательстве, что в судебной практике приводит к неисполнению судебных решений разных стран.

Решение данной проблемы видится в создании единых, унифицированных правил, которые детально регулировали бы все положения относительно перевозок, а не только ответственность сторон, передавая все остальные аспекты на регулирование национального законодательства.

И 4 проблема связана с отношением тайм-чартера к договору аренды. Тайм-чартер является видом фрахтования судна. Тайм-чартер, согласно статье 198 КТМ РФ, под таким договором понимают фрахтование судна на время вместе с экипажем для любых целей торгового мореплавания.

Тайм-чартер представляет собой сложный договор, содержащий в себе элементы аренды судна и услуги экипажа для конкретных целей в рамках комплекса услуг торгового мореплавания [3].

В США, Великобритании и Германии тайм-чартер является видом перевозок с рейсовым чартером, что закреплено в правовых нормах. В Польше тайм-чартер является самостоятельным видом, и не приравнивается ни к одному другому виду. Во Франции таймчартер является разновидностью фрахтования судна. В Российской Федерации в статье 632 ГК РФ такой вид морских перевозок имеет иную правовую природу, и является разновидностью договора аренды транспортного средства с экипажем. [1, ст. 632 Г РФ] Исходя из содержания данного вида перевозок, а также опыта других государств, 
представляется возможным внести поправку в Гражданский кодекс, исключить тайм-чартер из главы «договор аренды», и включить в главу 40 ГК РФ Перевозка и отнести к договору фрахтования.

Подводя итог, можно сделать вывод о том, что отличительной чертой международных морских перевозок является многообразие источников правового регулирования. Правовые обычаи, на сегодняшний день, носят опосредованный характер в правовом регулировании данных правоотношений. Стороны самостоятельно принимают решение об использовании норм в регулировании возникающих между ними отношений, в связи с чем при рассмотрении споров данные нормы не всегда учитываются. Положения же конвенций, принятых еще в двадцатом веке, устарели, и не совсем соответствуют условиям современной действительности. Необходимо внести правки в части регламентирования прав и обязанностей сторон, освобождения от ответственности, порядка рассмотрения споров и применимого к ним законодательства, в том числе нормы о возможности ведения электронного документооборота.

$$
* * *
$$

1. Гражданский кодекс Российской Федерации. Часть первая: федер. закон от 30.11.1994 г. № 51-Ф3 // Собр. законодательства Рос. Федерации. 2007. № 32. Ст. 3301. 2018. № 32 (Часть II). Ст. 5132. (ред. от 09.03.2021)

2. Кодекс торгового мореплавания Российской Федерации: федер. закон от 30.04.1999 № 81-Ф3 // Собр. законодательства Рос. Федерации. 1999. № 18. Ст. 2207. (ред. от 26.05.2021).

3. Лобзов, Г.П. Чартерные перевозки: виды и особенности / Г.П. Лобзов // E-Scio. 2020. № 10. С. 35-40.

\section{Ляпустина Н.А. \\ Новации в сфере образования}

Владивостокский государственный университет экономики и сервиса (Россия, Владивосток)

doi: 10.18411/trnio-09-2021-80

\section{Аннотация}

Статья посвящена последним нововведениям в сфере образования. Автором был проведён анализ введённых законодательных новшеств, в результате которого дана оценка их положительных и негативных черт.

Ключевые слова: новации, образование, студент, преподаватель, учитель.

\section{Abstract}

The article is devoted to the latest innovations in the sphere of education. The author analyzed the introduced legislative innovations, as a result of which an assessment of their positive and negative characteristics was given.

Keywords: innovation, education, student, university lecturer, school teacher.

Образование помогает человеку раскрыть потенциал, сформировать такие качества как дисциплина, целеустремленность. Современному человеку практически невозможно жить в настоящих реалиях без образования. Любое государство нуждается в большом количестве специалистов в различных областях, чтобы оно имело право не только на существование, но и на развитие, прогресс. Наше государство не исключение. Понимая важность образования, оно утверждает новые положения, которые делают его наиболее соответствующим требованиям реального времени.

1. Одно из нововведений - бесплатное второе высшее образование в области искусств. Граждане России, уже получившие высшее образование бесплатно, смогут воспользоваться правом на получение ещё одного высшего образования, а именно в области искусств, за счёт бюджетных 